\title{
Determinants of Successful Implementation of Geothermal Projects in Kenya: A Survey of Menengai and Olkaria
}

\author{
Jeremiah Kipngok $^{1}$, Dr. Daniel Wanyoike ${ }^{2}$, Hosea Kemboi ${ }^{3}$ \\ ${ }^{1}$ Geothermal Development Company, P.O. Box 17700 - 20100, Nakuru \\ ${ }^{2}$ Lecturer, School of Entrepreneurship, Procurement and Management, JKUAT, Nakuru CBD Campus, Kenya
}

\begin{abstract}
Geothermal energy has been accelerated by the Kenya government as a strategic objective towards addressing the serious constraints in energy supply and cost in the country. Despite the vast geothermal resources Kenya is endowed with, estimated to be in excess of $7000 \mathrm{MW}$, only a small fraction, approximately 8\%, has been exploited leaving a huge portion still untapped. This study thus sought to investigate the critical factors that significantly affect implementation of geothermal development projects in Kenya by the key implementing agencies, GDC and KenGen. The research employed a multiple case study design where stratified random sampling technique was used. Data was collected using survey questionnaires and key informant interviews. The Statistical Package for Social Sciences (SPSS version 17) was used to run descriptive statistics such as frequency and percentages so as to present the quantitative data based on the research objectives. Qualitative data generated from open ended questions was categorized in themes in accordance with the research objectives and reported in narrative form along with quantitative results. Pearson's correlation coefficient was employed to analyze inferential statistics and test the hypotheses of the study. The findings show that all the four determinants considered in this study, that's strategy, funding, geothermal resource uncertainty and technical capacity, are positively correlated to successful implementation of geothermal projects in Kenya and are responsible for explaining $71 \%$ of project implementation. It is concluded that the government plays a central role as far as successful implementation of geothermal projects is concerned. The researcher recommends harmonization (streamlining) of laws and regulations that guide and govern geothermal development as well as enactment of policies and guidelines that provide a clear framework of handling communities that host geothermal resources. It is further recommended that the government expedites the setting up of Geothermal Centre of Excellence to bridge the gap in local expertise.
\end{abstract}

Keywords: GDC, KenGen, geothermal resources, project implementation, geothermal projects, critical determinants

\section{Introduction}

Energy plays a fundamental role in the economy of any nation as well as having a significant potential for poverty reduction and wealth creation. Adequate and reliable supply of energy is central to achieving sustainable development goals including the Millennium Development Goals (Rogner, 2012). However, secure, reliable, affordable, clean and equitable energy supply, which is fundamental to global economic growth and human development presents huge challenges for all with 1.2 billion people globally without access currently (WEC, 2014).Over the last few decades though, many technologies have been developed in the world to harness geothermal energy source and many countries currently use this energy for electricity generation and for various direct uses. Geothermal power was online in at least 24 countries in the year 2013 (Matek, 2014). The global geothermal power market hence continues to grow substantially, with exciting new opportunities arising around the globe (GEA, 2013). It has further been noted that the international geothermal power market is booming, growing at a sustained rate of $4 \%$ to $5 \%$ (Matek, 2014). Geothermal power generation is therefore expected to soon move from marginal to mainstream.

Kenya is one of the leading countries globally with vast geothermal resources estimated at 7000 to $10,000 \mathrm{MWe}$ from geo-scientific surface exploration surveys (Simiyu, 2010; Ngugi, 2012; Mulaha, 2013; Omenda \& Simiyu, 2015). The estimated geothermal resource is associated with the volcanic centres that dot the Kenya Rift Valley, part of the eastern arm of the East African Rift System (Omenda, 2007; Omenda, 2012). The road to geothermal development in Kenya started in the 1950s with exploration studies culminating in the drilling of the first geothermal exploration wells in Olkaria between 1956 and 1959 (Karingithi, 2012; Saitet \& Muchemi, 2015). The wells never discharged though and were later abandoned. Further assessment of the geothermal resource was however undertaken later in the 1960s leading to the drilling of more wells between 1971 and 1976. These wells turned out to be successful, giving positive results and drilling was subsequently accelerated that resulted to the commissioning of the first $45 \mathrm{MW}$ power plant between 1981 and 1985 (Karingithi, 2012). Subsequently, continued expansion and development of the geothermal resources in the country has been ongoing for about three decades now.

Over the recent few years, development of geothermal energy in the country has been accelerated as a strategic objective in addressing increasing demands for electricity. This is in recognition of the fact that affordable electric power is no doubt a key element of the "social" and "economic" pillars envisioned in Kenya"s Development Agenda dubbed Vision 2030 (Mwakubo et al., 2007; MoEP, 2014).According to LCPDP (2011) report, geothermal resources are the choice for the future generating capacity in Kenya. The optimum solution indicates that geothermal capacity should be increased from the current $573 \mathrm{MW}$ (Omenda \& Simiyu, 2015) to 5,530 MW in the planning period (LCPDP, 2011), equivalent to $26 \%$ of the system 


\section{International Journal of Science and Research (IJSR) \\ ISSN (Online): 2319-7064}

Index Copernicus Value (2013): 6.14 | Impact Factor (2014): 5.611

peak demand by 2031. Geothermal, being notably one of the chief options in Kenya, is not affected by drought and climate variability with the highest availability at over $95 \%$ (Kollikho\&Rivard, 2013).

As of March, 2015, the installed electric power generation capacity from geothermal sources in Kenya was 573 MW, accounting for about $30 \%$ of the country sinstalled capacity (Omenda \& Simiyu, 2015; Saitet \& Muchemi, 2015). Moreover, generation of additional $105 \mathrm{MW}$ is also expected from the Menengai Geothermal Field contributing towards achieving at least $1900 \mathrm{MW}$ of electricity by 2017 (MoEP,

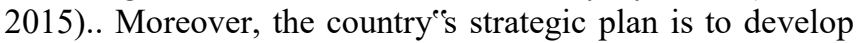
and install in excess of $1600 \mathrm{MW}$ from geothermal sources by the year 2016 and 5000 MW by the year 2030 (MoEP, 2014).

\section{Motivation for Research}

The energy situation in Kenya has for several years been characterized by inadequate and irregular supply, low access and high cost (LCPDP, 2011). Yet on the other hand, secure, reliable, affordable, clean and equitable energy is no doubt fundamental to sustaining and improving Kenyaes economic growth rate that was projected at $6.5 \%$ in 2015 (UNDP, 2015), as well as crucial to achieving the countryes envisioned Development Agenda dubbed Vision 2030. Presently, only a small fraction (about $8 \%$ ) of the much needed and vast geothermal resource in the country has been exploited, implying that a huge potential remains untapped. Whilst the strategic plan for example, indicates that 1900 MW is planned to come online by 2017 , it appears that a total of approximately $580 \mathrm{MW}$ will have been installed by end of 2015 (MoEP, 2015). It is therefore apparent that understanding the key determinants of implementation of geothermal projects is crucial to achieving these ambitious targets.

The researcher acknowledges the various studies conducted on projects that consume huge financial resources undertaken by the government of Kenya and development partners. A research particularly by Kagiri and Wainaina (2008) investigated factors that significantly contributed to time and cost overruns on power projects implemented by KenGen but its scope was wide and was not particular to geothermal development. Consequently, to the best of the researcher's knowledge, studies with regard to critical determinants of implementation of geothermal projects in Kenya have either not been conducted or that the findings of such studies have not been published in open literature. This research thus sought to examine what critically influences implementation of geothermal development projects in Kenya.

\section{Research Objectives}

This research was guided by the following objectives:

1) To determine the influence of strategy on the implementation of geothermal projects in Kenya.

2) To assess the effect of funding on the implementation of geothermal projects in Kenya.
3) To examine the influence of geothermal resource uncertainty on the implementation of geothermal projects in Kenya.

4) To evaluate the effect of technical capacity on the implementation of geothermal projects in Kenya.

\section{Hypothesis of the Study}

Ho 1: There is no significant influence of strategy on implementation of geothermal projects in Kenya.

$\mathbf{H o}_{2}$ : There is no significant influence of funding on implementation of geothermal projects in Kenya.

Ho 3: There is no significant influence of geothermal resource uncertainty on implementation of geothermal projects in Kenya.

$\mathbf{H o}_{4}$ : There is no significant influence of technical capacity on implementation of geothermal projects in Kenya.

\section{Conceptual Framework}

The study sought to gain insight on the critical factors that significantly contribute to successful implementation of geothermal projects in Kenya. Four elements were identified from the studyes background information which constitute the independent variables in the study. Implementation of geothermal projects is the dependent variable. A diagrammatic representation depicting the relationship between the dependent variable and the independent variables is presented in Figure 2.1 in line with conceptual framework definition and discussions by Young (2009), Huberman (1994) and Mungenda (2008). The variables must be explained in relation to each other as well as to their individual impact on successful project implementation.

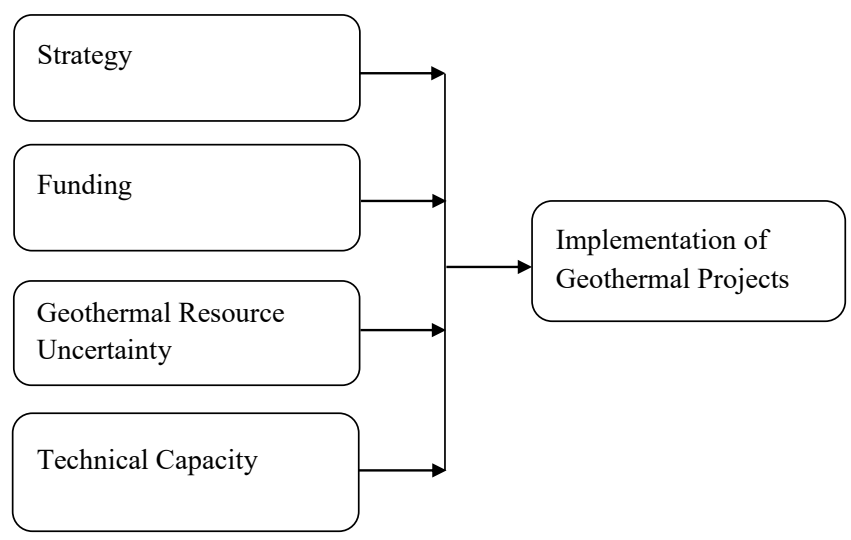

Independent variables Dependent variable

Figure 1: Conceptual Framework

\section{Research Methodology}

The research utilized a multiple case study design owing to the fact that case studies based on multiple sources of evidence have proven to be rated higher in terms of overall quality than those that relied on a single source of information (Yin, 1994). The aim was to develop a detailed, intensive knowledge on the few cases of government supported geothermal development projects which are being carried out both in the Menengai and Olkaria Geothermal 


\section{International Journal of Science and Research (IJSR) \\ ISSN (Online): 2319-7064}

Index Copernicus Value (2013): 6.14 | Impact Factor (2014): 5.611

Fields in Kenya.Yin (1994) further claimed that the use of multiple cases yields more robustness to the conclusions from the study. The projects investigated were at various stages of development, from geoscientific surface exploration to drilling and power generation. Data was collected from senior staff in both GDC and KenGen who were divided into two categories, that's top level and midlevel management taking into account the kind of information sought in order to meet the objectives of the study. The target respondents were considered to possess adequate knowledge about geothermal projects that were already implemented and those under implementation by the two companies. A total of 164 respondents were nominated from a population of 279 to participate in the survey.

Survey questionnaires and key informant interviews were used as the primary tools for obtaining data.The questionnaire comprised two main parts; part II that sought to capture the general particulars of the respondentand part III which focused on the four determinants that formed the independent variables of the study.Part III gave each respondent an opportunity to identify variables that they perceive to have contributed to geothermal projectsuccess by responding on a Likert scale from 5 (strongly agree) to 1 (strongly disagree). The questionnairesand interview schedules were validated by three individuals/experts working in the geothermal firms and pilot tested using 25 participants who did repeat the exercise after one week with an aim of establishing the reliability of the data collection instrument. The scores obtained from both tests were correlated to yield a Cronbaches Alpha of 0.871 and was considered good for the study given that a correlation coefficient of 0.7 and above is considered acceptable for the study according to Fraenkel\&Wallen (2000). The final questionnaire was hand delivered to the respondents since this method eliminates non-coverage errors associated with the mail method. Additionally, the researcher interviewed two experts each from both GDC and KenGen using an interview guide comprising eight numbers of test items. It took approximately 45 minutes to interview each expert. The experts interviewed had varied years of experiences in the geothermal sector that spanned a period between 15 and 26 years and thus considered to possess sufficient expertise on matters geothermal.

\section{Data Analysis}

Both quantitative and qualitative approaches were used for data analysis. Quantitative data from the questionnaire were coded and keyed into the computer for computation of descriptive statistics. The Statistical Package for Social Sciences (SPSS version 17) was used to run descriptive statistics such as frequency and percentages so as to present the quantitative data in form of tables and graphs. Qualitative data generated from open ended questions were categorized in themes in accordance with the research objectives and reported in narrative form along with quantitative data. The qualitative data was used to reinforce the quantitative data. Pearson's correlation coefficient was employed to analyze inferential statistics and the degree of relationship between the variables in the study. Hypotheses testing were done using Pearson's correlations and t-test at $95 \%$ confidence level.

\section{Research Findings}

A total of 137 out of 164 questionnaires issued to top and the mid-level management staff working at the Olkaria geothermal project (KenGen) and those at GDC who are involved in the Menengai geothermal project were properly filled and returned giving a response rate of $83.5 \%$. This was considered very appropriate since a response rate of $50 \%$ is deemed adequate to establish the research objectives while $60 \%$ is considered good and above $70 \%$ rated very good according to Mugenda\&Mugenda (2003). The findings from the interview schedules are also discussed according to the research objectives.

\subsection{Demographics}

This study sought the respondents "e background information of importance towards achieving its main purpose, which included: gender, age, education level and work department. The findings on gender showed that majority of the respondents were of males, forming $71.5 \%$ of the surveyed staff while the female gender constituted $28.5 \%$. This is inferred to reflect the nature of work in the geothermal firms which is largely technical with higher male to female ratio. It was also found that over $90 \%$ of the respondents were aged 30 years and above, with the majority (46\%) being in the age bracket of $30-34$ years. It is thus inferred that the larger population of respondents are in their prime years and were considered old enough to provide valuable responses that pertain to implementation of geothermal projects in Kenya and subsequently meet the objectives of the study. This is resonant with what was also observed in the years of work experiencewhereby over $75 \%$ have worked for at least four years in the geothermal companies. The findings on education levels of the surveyed staff indicated that majorityof the respondents $(51.1 \%)$ had masters degrees while $46 \%$ hadfirst degrees and the remaining had reached doctoral level. Moreover, it was found that majority of the respondents $(60 \%)$ belong to the technical division (comprising drilling, resource assessment and management and infrastructure departments), which typically forms the larger population of employees in the geothermal firms, whose operations are largely technical in nature. Overall, drawing from the background information and given that the respondents play both executive and supervisory roles in the geothermal companies, the researcher hopes that the information provided by these respondents sheds light on the key determinants of successful implementation of geothermal projects in Kenya.

\subsection{Inferential Analysis Results}

Inferential analysis was used to determine whether a relationship exists between contributing factors and the outcome, as well as the strength of that relationship. It uses statistical test to see if a pattern observed is just due to chance or as a result of cause and effect.Coefficient of correlation (R), which determines the degree (strength) of relationship and has a value between -1 to 1 , was used. Additionally, results from expert interviews are incorporated in the discussion of inferential analysis findings. 


\section{International Journal of Science and Research (IJSR) \\ ISSN (Online): 2319-7064}

Index Copernicus Value (2013): 6.14 | Impact Factor (2014): 5.611

\subsubsection{Strategy and its Contribution to Successful Implementation of Geothermal Projects}

As shown in Table 1, strategy has an R-value of .557 indicating a significant positive relationship between strategy and successful implementation of geothermal projects in Kenya. This is satisfactory to the first objective of the study: to determine the effect of strategy on the implementation of geothermal projects in Kenya. The $p$ values (.000) are below .05 and thus leads to rejection of the null hypothesis that there is no significant relationship between strategy and successful implementation of geothermal projects, at $5 \%$ level of significance. This finding is resonant with those of Gehringer \& Loksha (2012) and Haraldsson (2012) who cited the existence of an enabling environment as crucial to successful development of geothermal resources. It also agrees with Yarger (2006) who noted that formulation of a sound strategy facilitates a number of actions without which the achievement of desired results would be otherwise difficult.

Table 1: Strategy and Contribution to successful implementation of geothermal projects

\begin{tabular}{|c|c|c|}
\hline & & Strategy \\
\hline Successful & Pearson Correlation & $.557^{*}$ \\
\cline { 2 - 3 } $\begin{array}{c}\text { Implementation of } \\
\text { Geothermal Project }\end{array}$ & Sig. (2-tailed) & .000 \\
\cline { 2 - 3 } & $\mathrm{N}$ & 137 \\
\hline
\end{tabular}

*. Correlation is significant at the 0.05 level (2-tailed).

Moreover, survey results showed that there is generally political good will in Kenya towards successful implementation of geothermal projects as evidenced bythe government's efforts through putting in place supportive laws and regulations and outlining an ambitious plan on developing geothermal. Whilst it is evident that the government has done a lot to create an enabling environment, improvements are required in order to enhance implementation of geothermal projects. The findings showed that there is need to harmonize (streamline) the laws that guide and govern geothermal resource exploration and exploitation. It is noted that if this would happen, it would expedite the process of acquiring the necessary permits that expedite geothermal development. The study further found that geothermal resource host communitiese issues, particularly when it comes to land and compensation is a very grey area that requires clear and defined guidelines from government on how to go about. Additional issues ensuing from the community that were pointed out include: security concerns in areas where neighboring communities are in conflict, which can significantly delay project implementation; community traditions and beliefs can also create resistance to development of geothermal resources, especially where communities consider geothermal sites sacred and thus jealously protect them, ecological values, for example developing geothermal resources hosted in ecologically restricted or conserved areas like Lake Bogoria is not feasible. These aspects were considered strategic as far as implementation of geothermal projects is concerned.

Another factor cited as a crucial strategic factor is infrastructure. It was found that there is generally capacity to carry out infrastructural works except that it requires a huge financial budget. Vast geothermal potential is found in remote and inaccessible areas and thus require significant funding to construct roads and water pipelines. Electricity evacuation/transmission is another infrastructural work needed. It was found that is need to expand power transmission lines, especially to cover Kenyaes North Rift which also host significant geothermal resources. The study also found that from experience, of every three wells drilled, one is likely to be unsuccessful. Additionally, it was noted that it takes about 90 days to complete drilling of one well and thus concluded from the findings that planning of geothermal projects should be done with such inherent geothermal resource development uncertainties in mind.

\subsubsection{Funding and its Contribution to Successful Implementation of Geothermal Projects}

As shown in Table 2, funding has an R-value of .324 indicating a significant positive relationship between funding and successful implementation of geothermal projects in Kenya. This is satisfactory to the second objective of the study, that's to determine the effect of funding on the implementation of geothermal projects in Kenya. The $p$ values (.000) are below .05 and thus leads to rejection of the null hypothesis that there is no significant relationship between funding and successful implementation of geothermal projects in Kenya, at 5\% level of significance. Therefore funding is positively correlated to successful implementation of geothermal projects in Kenya.

Table 2: Funding contribution to successful implementation of geothermal projects

\begin{tabular}{|c|c|c|}
\hline & & Funding \\
\hline Successful & Pearson Correlation & $.324^{*}$ \\
\cline { 2 - 3 } Implementation of & Sig. (2-tailed) & .000 \\
\cline { 2 - 3 } Geothermal Project & $\mathrm{N}$ & 137 \\
\hline
\end{tabular}

*. Correlation is significant at the 0.05 level (2-tailed).

The study findings showed that finances are key to implementation of geothermal projects, citing that on average for example, it costs about 3.5 to 5 million USD to develop 1 MWe of geothermal power. This inference supports the findings of IFC (2013), Gehringer \& Loksha (2012) and MoEP (2015) which cited finances as crucial to the success of geothermal projects. However, it was pointed out that the main challenge with obtaining finances is generally the high risk inherent in geothermal resource development. The cited risks include: risks associated with the nature of geothermal resources (resource risk); drilling risk (upfront risk), which was seen to be responsible for making most financiers shy away from funding drilling activities because of the extremely high cost incurred with no guaranteed results, and market risk, which entails the need for availability of a ready market for steam, which is so key to the extent that power purchase agreements become necessary.

It was also found that while there exists financial prudence, inadequacy of funds was experienced during geothermal project implementation. This was attributed tolong lead times and cash flow issues from government. Moreover, financial planning was also seen to contribute toinsufficiency in funding having been cited to suffer from poor scoping, whereby technical specs are sometimes vague and do not capture all the elementspertaining project 


\section{International Journal of Science and Research (IJSR) \\ ISSN (Online): 2319-7064}

Index Copernicus Value (2013): 6.14 | Impact Factor (2014): 5.611

implementation. This was observed to occur due to shortage of or limitations in technical skills. What came out strongly from the study is that improvement is needed, particularly on the aspect of scoping of work. It was also found that the government needs to provide more tax incentives through tax exemptions. Whereas this was noted to have been provided for in policy, it was observed that it is usually an uphill taskin reality. The consequence of providing tax incentives, coupled with good policy framework and the price of geothermal steam would attract and encourage/promote funding of geothermal projects.

\subsubsection{Geothermal Resource Uncertainty and its Contribution to Successful Implementation of Geothermal Projects}

As shown in Table 3, geothermal resource uncertainty has an R-value of .466 indicating a significant positive relationship between geothermal resource uncertainty and successful implementation of geothermal projects. This is satisfactory to the third objective of the study: to determine the influence of geothermal resource uncertainty on the implementation of geothermal projects in Kenya. The p values (.000) are below .05 and thus leads to rejection of the null hypothesis that there is no significant relationship between geothermal resource uncertainty and successful implementation of geothermal projects, at $5 \%$ level of significance.

Table 4.8: Geothermal resource uncertainty and successful implementation of projects

\begin{tabular}{|c|c|c|}
\hline & & $\begin{array}{c}\text { Geothermal } \\
\text { Resource } \\
\text { Uncertainty }\end{array}$ \\
\hline $\begin{array}{c}\text { Successful } \\
\text { Implementation of } \\
\text { Geothermal Project }\end{array}$ & Pearson Correlation & $.466^{*}$ \\
\cline { 2 - 3 } & Sig. (2-tailed) & .000 \\
\cline { 2 - 3 } & $\mathrm{N}$ & 137 \\
\hline
\end{tabular}

*. Correlation is significant at the 0.05 level (2-tailed).

The study found out that geothermal resource uncertainties are responsible for much of the delays experienced in implementing geothermal projects. The findings agreed with those brought out by Gehringer \& Loksha (2012) that correct geothermal resource assessment is considered very essential, particularly in regard to obtaining sufficient and accurate information on the geothermal resource at every stage of development resulting to having a sufficiently correct/accurate conceptual model of the geothermal system. It was noted from the survey that adequate surface exploration studies are conducted and feasibility studies are carried out at every stage of geothermal development in Kenya in keeping with worldwide best practices as outlined by Arnórsson (2000), Marcou (1985), Gehringer \& Loksha (2012), Mwangi (2007) and Kanda, Kipngok, Keter, \& Ochieng (2013) who remarked the significance of step-wise development of geothermal resources. It was observed though that the consequence of this is long lead times, which was cited as affecting not only the timelines set for implementation of the projects but financiers as well. The findings found that most financiers only commit funds once $50 \%$ of steam required has been proved while being compounded by the need to produce surplus steam (about $10 \%$ of required) is so as to provide the necessary buffer during exploitation/power generation. Accordingly, it wasnoted that whereas this is the best strategy towards minimizing uncertainty, it has the potential of causing costly delays to geothermal projects.

Moreover, survey results showed that the likelihood of depleting geothermal reservoirs before the stipulated period of exploration for electricity generation is very low as well as the possibility of having a volcanic eruption in geothermal prospect areas in Kenya. It was also pointed out that quality of geothermal fluids which include temperature, enthalpy and chemistry, can affect the success of a geothermal projectin agreement with observations made by IFC (2013) that geothermal resource uncertainty can affect the quality and quantity of production, and thus the succes of geothermal projects.It was however pointed out that challenges with fluid characteristic have and can be mitigated to a large extent. The findings concluded that having adequate human expertise goes a long way in minimizing geothermal resource uncertainties through obtaining accurate information on the geothermal resource at every stage/phase of development.

\subsubsection{Technical Capacity and its Contribution to successful implementation of projects}

As shown in Table 4, technical capacity has an R-value of .254 indicating a significant positive relationship between technical capacity and successful implementation of geothermal projects. This is satisfactory to the fourth objective of the study: to determine the effect of technical capacity on the implementation of geothermal projects in Kenya. The $\mathrm{p}$ values (.000) are below .05 and leads to rejection of the null hypothesis that there is no significant relationship between technical capacity and successful implementation of geothermal projects, at 5\% level of significance. Therefore technical capacity is positively correlated to successful implementation of geothermal projects in Kenya. This finding is consistent with those of Pinto and Slevin (1987), Bruch \& Ghoshal (2003), Shenhar (2004) and Martin (2011) who identified human capacity as a very crucial tactical component in project implementation, and those of Mwangi (2010), Kollikho \& Rivard (2013) and Mariita (2015) who cited lack of human expertise as affecting accelrated development of geothermal resources in Kenya.

Table 4: Technical Capacity and Contribution to successful implementation of project

\begin{tabular}{|l|c|c|}
\hline \multicolumn{2}{|c|}{} & Technical Capacity \\
\hline Technical & Pearson Correlation & $.254^{*}$ \\
\cline { 2 - 3 } Capacity & Sig. (2-tailed) & 0 \\
\cline { 2 - 3 } & N & 137 \\
\hline
\end{tabular}

*. Correlation is significant at the 0.05 level (2-tailed).

Survey results indicated that human capacity is central towards implementation of geothermal projects in Kenyaciting that the projected electricity to be generated (MWe) against optimized staff shows a significant deficit in skilled technical staff. It was noted that in order to achieve the geothermal energy ,dream, "a good number of personnel with a good level of knowledge and skills (expertise) are required. The findings indicated that in order to obtain sufficiently accurate geothermal resource data and other 


\section{International Journal of Science and Research (IJSR) \\ ISSN (Online): 2319-7064 \\ Index Copernicus Value (2013): 6.14 | Impact Factor (2014): 5.611}

relevant information, which is critical for the success of geothermal projects, availability of personnel who are well equipped with the relevant technical knowledge and skills (expertise) is crucial. Moreover, shortage of technical capacity has led to engaging of foreign consultants to supplement requirements. It was observed that to bridge this gap, more staff would need to be hired and equipped, although it was remarked that it is expensive to train or equip staff with relevant knowledge and skills on geothermal development. The survey results also showed that opportunities for staff career growth existed and that leadership of the implementing companies, GDC and KenGen, was committed to steering well implementation of geothermal projects in the country. It was also observed that technology for harnessing geothermal resources is generally available, although more needs to be done on utilization of medium enthalpy geothermal resources.

The findings further showed that currently, partnerships with institutions like UNU-GTP, JICA, USAID and ICEIDA among others, have made valuable contributions to capacity building, as well as input from advisory boards comprising experts across the world who are usually engaged to provide expert opinions and advice on geothermal projects in the country. Notably, the findings indicated that the upcoming Geothermal Centre of Excellence was cited to contribute significantly to building human capacity and thus would go a long way in bridging this gap. Geothermal Centre of Centre of Excellence is expected to achieve results similar to what KPLC benefits from its training school. Additionally, the findings shows that establishing a Geothermal Centre of Excellence would give Kenya an opportunity to establish herself regionally as a leader in geothermal resource development as well as provide a crucial platform for dissemination of knowledge in the region. It was further found that there is need to build capacity of engineers to handle contracts that deal with equipment and installations in order to reduce overreliance on foreign companies so as to boost local companies and thus benefit the countryes economy more. Generally, the findings strongly brought outthe need to strengthen human capacity, in terms of skills and numbers, if the envisioned goal of producing $5000 \mathrm{MWe}$ by 2030 is to be realized.

\section{Regression Analysis}

Multivariate regression analysis was used to determine the significance of the relationship between the dependent variable and all independent variables pooled together. This analysis was used to answer the questions; how do the independent variables influence the dependent variable collectively; to what extent does each independent variable affect the dependent variable in such a collective set-up, and; which are the more significant factors? Table 5 gives the model summary of the multiple linear regressions.

Table 5: Multiple linear regression analysis model summary

\begin{tabular}{|l|c|c|c|c|}
\hline Model & $R$ & $R$ Square & Adjusted R Square & $\begin{array}{c}\text { Std. Error of the } \\
\text { Estimate }\end{array}$ \\
\hline 1 & $.756^{\mathrm{a}}$ & .722 & .711 & .413 \\
\hline $\begin{array}{l}\text { a. Predictors: (Constant), Strategy, Funding, Geothermal resource } \\
\text { uncertainty, Technical capacity }\end{array}$ \\
b. Dependent Variable: Implementation of geothermal projects \\
\hline
\end{tabular}

The results in Table 6 showed that the value obtained for $R$, which is the model correlation coefficient was $\mathrm{R}=.756$ which is higher than any zero order value in the table. This indicates that the model improved when more variables were incorporated when trying to analyze the determinants of geothermal project implementation in Kenya. The adjusted $\mathrm{R}^{2}$ value of $\mathrm{R}^{2}=0.711$, also indicated that the multiple linear regression model could explain for approximately $71.1 \%$ of the variation in the determinants of implementation of geothermal projects. To answer the question pertaining to which of the independent variables is more important in influencing performance of geothermal energy projects (the beta value), a summary of the results is given in Table 6 .

Table 6: Regression Model

\begin{tabular}{|c|c|c|c|c|}
\hline \multirow{2}{*}{ Model } & \multicolumn{2}{|c|}{$\begin{array}{c}\text { Unstandardized } \\
\text { Coefficients }\end{array}$} & $\begin{array}{c}\text { Standardized } \\
\text { Coefficients }\end{array}$ & \multirow{2}{*}{ Sig } \\
\cline { 2 - 5 } & $B$ & $\begin{array}{c}\text { Std. } \\
\text { Error }\end{array}$ & Beta & \\
\hline (Constant) & $\mathbf{2 . 8 9 7}$ & $\mathbf{. 4 2 9}$ & & $\mathbf{. 0 0 0}$ \\
\hline Strategy & .231 & .070 & .285 & .001 \\
\hline Funding & .052 & .049 & .090 & .013 \\
\hline $\begin{array}{c}\text { Geothermal Resource } \\
\text { Uncertainty }\end{array}$ & .017 & .0551 & .028 & .007 \\
\hline Technical capacity & .124 & .069 & .153 & .003 \\
\hline
\end{tabular}

a. Dependent Variable: Implementation of geothermal projects

From the regression model in Table 6, the regression equation was obtained. Using the unstandardized beta coefficients, the following regression equation was developed.

$$
\mathrm{Y}=2.897+0.231 \mathrm{X}_{1}+0.052 \mathrm{X}_{2}+0.017 \mathrm{X}_{3}+0.124 \mathrm{X}_{4}+\varepsilon
$$

From the full regression model, the beta values were obtained which explain the regression equation. The standardized beta coefficients give a measure of influence of each variable to the model. Regarding the influence of factors affecting project implementation, the study revealed that the strategy determinant had the greatest influence on implementation of geothermal projects in Kenya $(\beta=.231)$, followed by technical capacity $(\beta=.124)$, then funding $(\beta=.052)$ and lastly, the determinant that had the least influence on implementation of geothermal projects in Kenya was geothermal resource uncertainty $(\beta=.017)$.

\section{Conclusions}

After incisively summarizing the study findings, the researcher was able to draw several pertinent conclusions which touched on all the research objectives. All the four determinants considered in the study, that's strategy, funding, geothermal resource uncertainty and technical capacity, were found to be positively correlated to successful implementation of geothermal projects in Kenya.Further, it was found that these variables are responsible for explaining about $71 \%$ of geothermal project implementation, and the remaining percentage could be due to other factors.

The survey results indicated that strategy is the determinant that has the most influence on implementation of geothermal projects in Kenya. Political support/good will was found to play a significant role in accelerating implementation of 


\section{International Journal of Science and Research (IJSR) \\ ISSN (Online): 2319-7064}

Index Copernicus Value (2013): 6.14 | Impact Factor (2014): 5.611

geothermal projects, particularly by creating an enabling environment and absorbing upfront risks through funding the initial stage of geothermal development, especially drilling. It is concluded that whereas the government has made significant efforts to this effect, there is still need to harmonize the laws that guide and govern implementation of geothermal projects in Kenya. The government further needs to develop policies and guidelines on how to handle projects that fall on community owned land to avoid unnecessary and costly delays on the implementation of these projects. Overall, it is concluded that the governmentes contribution is central if success is to be realized in implementation of geothermal projects.

Funding was found to be crucial to successful implementation of geothermal projects as it was seen to facilitate most of the elements of project implementation. It is noted that the government shoulders most of the financial responsibility, directly and indirectly as part of its strategy to accelerate development of geothermal resources. While the private sector is shy to invest in geothermal projects, especially at the initial stage due to the high risks and uncertainties inherent, the government has made significant efforts to encourage their participation and it is expected that this situation will change in the near future.

It is apparent from the study that obtaining sufficient and accurate information about the geothermal resource(s), that's its presence, nature and quality, is critical. It thus implies that personnel, with the necessary expertise play an important role towards achieving this. Generally, development of geothermal in Kenya employs the stepwise strategy which is the best practice/technique worldwide aimed at improving the certainty of the resource information. Overall, it is concluded that it is not possible to completely eliminate geothermal resource uncertainties but they can be minimized through staging development as well as mitigation.

The findings furtherindicated that it is paramount to invest in training so as to acquire highly skilled manpower, particularly of scientists and engineers, because geothermal development requires a unique set of knowledge and skills. It is concluded from the findings that the establishment of a Geothermal Centre of Excellence will go a long way towards reducing the cost in time and money of capacity building.

\section{Recommendations}

After drawing the aforementioned inferences, the researcher deemed it rational to put across a number of pertinent recommendations. The researcher recommends that;

Firstly, the government expedites the setting up of Geothermal Centre of excellence so to bridge the gap in the local human capacity/expertise as well as significantly minimize reliance on foreign experts.

Secondly, more refined guidelines from government should be enacted with regard to off takers. Generally, alignment of players in the sector which include GDC, KenGen, KETRACO and KPLC should be done by the government to expedite the overall process from power generation to distribution to consumers.

Thirdly, there needs to be a clear way of handling geothermal resource host communities, particularly when it comes to land and compensation. The government needs to provide a clear direction in the form of policy and guidelines in order to minimize the cost of compensation and subsequently avoid losing valuable time and money, as there is no properly defined way of handling government projects that fall in/within community owned land.

Fourthly, the government needs to provide more tax incentives, particularly through tax exemptions. In so doing, the private sector will be more encouraged to invest in geothermal development. Whereas the government provides this in policy, the findings noted that it takes quite long (not less than six months) currently to acquire tax exemptions in Kenya, making the process tedious and usually unfeasible. There is need for improvements on policy and procedures so as to facilitate the process. If tax exemptions is achieved, it was noted, drilling costs could be significantly reduced (by nearly half the current costs).

\section{Further Research}

The researcher recommends the following areas for further research:

- Detailed study on factors that lead to time and cost overruns during implementation of geothermal projects so as to shed more light on the actual cause of inadequacy of funds experienced during implementation of geothermal projects.

- Examine the obstacles that the government, in providing the essential political support, encounters in creating a more enabling environment for implementation of geothermal and other related projects.

- Assess the challenges encountered with geothermal resource host communities and how they could be overcome in order to enhance the speed of implementing geothermal and other projects hosted in community owned land.

\section{References}

[1] S. Arnórsson, "Strategy in Geothermal Exploration, Development and Production in: Isotopic Techniques in Geothermal Exploration, Development and Use." Vienna, 2000.Intertional Atomic Energy Agency.

[2] H., Bruch \&S.Ghoshal, "Unleashing organizational energy."MIT Sloan Management Review, 2000, 45(1), 45.

[3] GEA. "International Geothermal Power Project List."2013 GEOTHERMAL POWER: INTERNATIONAL MARKET OVERVIEW , p. 35.2013, September.

[4] M Gehringer., \&V. Loksha, "Geothermal Handbook: Planning and Financing Power Generation" Washington, DC: Energy Sector Management Assistance Program (ESMAP), 2012.

[5] G. Haraldsson, "Legal and regulatory framwork Barrier or Motivation for Geothermal 


\section{International Journal of Science and Research (IJSR) \\ ISSN (Online): 2319-7064}

Index Copernicus Value (2013): 6.14 | Impact Factor (2014): 5.611

Development."Short Course on Geothermal Development and Geothermal Wells" organized by UNU-GTP and LaGeo, Santa Tecla, El Savador, p. 24.March 11- 17, 2012.

[6] A. M. Huberman, "Pharmaceutical Chain Management", 6th ed. London1994.

[7] IFC. Success of Geothermal Wells: A Global Study. Washington, DC: 2013. International Finance Corporation.

[8] D.Kagiri\& Wainaina, G. Time and Cost Overruns in Power Projects in Kenya: A Case Study of Kenya Electricity Development Compnay. 4th International Operations Research Society of Eastern Africa (ORSEA) (p. 29), 2008. Kampala: ARCHWAY Technology Management Ltd.

[9] I. K.Kanda, J. K., Kipngok, M. S., Keter, \&L. Ochieng. "Prioritization in the Development of Geothermal Fields:The Kenyan Context. The JKUAT Scientific, Technological and Industrialization." Conference (p. 9). Nairobi: Jomo Kenyatta University of Agriculture and Technology, 2013.

[10]C. Karingithi. Geothermal Development in Kenya. Washington D.C.: Climate Investment Funds (CIF), 2012

[11]P., Kollikho, \&B. Rivard,"Harnessing geothermal energy: The case of Kenya."Climate Development Knowledge Network, 2013.

[12]LCPDP, "Updated Least Cost Power Development Plan.” Nairobi: Ministry of Energy, Kenya, 2011.

[13] J. A.Marcou, "Optimizing Development Strategy for Liquid Dominated Reservoirs.”California: Stanford University, 1985.

[14] O. N. Mariita,"Status and Challenges in Training on Geothermal Energy in Africa."Proceedings World Geothermal Congress 2015 (p. 3 p). Melbourne: World Geothermal Congress (WGC).

[15]N. A. Martin, "Project Politics: A Systematic Approach to Managing Complex Relationships."2011, Gower publication.

[16] Geothermal Power: International Market Overview, p. 35.

[17]B. Matek, “Annual United States \& Global Geothermal Power Production Report." 2014, California, USA: GEA.

[18] A. H. Mbwambo, "Strategies and firm-level institutions in smallscale enterprise performance in Tanzania, The case of small-scale garment manufacturing firms." Nairobi: University of Nairobi (Doctoral dissertation)2005.

[19] MoEP, "Draft National Energy Policy. Nairobi Ministry of Energy and Petroleum.2014.

[20] MoEP,"Draft National Energy and Petroleum Policy." Nairobi, Kenya: Ministry of Energy and Petroleum, 2015.

[21]T. O. Mulaha, “An Overview of Geothermal Resources Development in Kenya. Nairobi:" Ministry of Energy and Petroleum,2013.

[22] A. G. Mungenda, "Social Science Research: Theory and Principles." Nairobi: Applied.

[23], O. M. Mugenda \&A. G. Mugenda, "Research methods: Quantitative and qualitative approaches." Nairobi,2003. Act press.
[24] Mwakubo, S., Mutua, J., Ikiara, M., \& Aligula, E. (2007). Strategies for Securing Energy Supply in Kenya. Nairobi, Kenya: KIPPRA.

[25] M. N. Mwangi, "The African Rift Geothermal Facility (ARGEO) - Status". Reykjavik: UNU-GTP, Iceland.

[26]N. M. Mwangi,"Planning of Geothermal Projects: A Case Study on Kenya. Short Course II on Surface"November 2 - 17). Exploration for Geothermal Resources, organized by UNU-GTP and KenGen, p. 12.

[27]P. Ngugi, , “ Kenya's Plans for Geothermal Development - A giant Step Forward for Geothermal. Short Course on Geothermal Development and Geothermal Wells, p. 8, 2012, March 11-17.

[28]P. A.Omenda,Status of Geothermal Exploration in Kenya and Future Plans for Its Development." Reykjavik, Iceland: UNU-GTP, Iceland, 2007.

[29]P. A. Omenda "Geothermal Delopment: A Country Update - 2012"African Rift Geothermal Conference (ARGEO-C4) (p. 5). Nairobi, Kenya: ARGEO.2012.

[30] Omenda, P., \& S. Simiyu, "Country Update Report for Kenya 2010-2014.”Proceedings World Geothermal Congress 2015 (p. 11 p). Melbourne, Australia: World Geothermal Congress.

[31]H. -H. Rogner, "World Energy Demand and Supply."IAEA Reports, 2012, 03 15, p. 49.

[32], D. Saitet\&G. Muchemi,"Kengen Financing Mechanisms for Geothermal Projects in Kenya.'Proceedings World Geothermal Congress 2015 (p. 6). Melbourne, Australia: World Geothermal Congress (WGC).

[33] A. J. Shenhar, "Strategic Project Leadership: Toward a strategic approach to project management."R \& D Management, 2004, 34, 569-578.

[34] S. Simiyu, "Status of Geothermal Development in Kenya and Future Plans for Its Development."World Geothermal Congress, 2010. Bali, Indonesia.

[35] WEC."World Energy Issues Monitor.”World Energy Issues Monitor, 2014, 01p. 96.

[36] I. Young, "Phamaceutical and Corruption in Bangladesh: Confronting the Challenges and the Opportunities."Journal of Public Administration and Policy Research, 2009, 103 - 111.

[37]R. Yin, "Case Study Research Design and Methods", 2nd ed., 1994, Applied Social Research Methods Series, Sage, Volume 5.

\section{Author Profile}

Jeremiah Kipngok received BSc in Mathematics and Chemistry from JomoKentyatta University of Agriculture and Technology in 2001. He was involved in fieldwork with Kenya Electricity Generating commonly between 2004 and 2005 before joining an Institute of Advanced Technology in 2006 where he was involved in training various IT courses including programming until 2009. The author then joined Geothermal Development Company as a Geochemist where he works to date. He also done a six month post graduate course in the Chemistry of Thermal Fluids under United Nations University, Geothermal Training Programme (UNU-GTP) in Iceland. He has authored and co-authored several papers on geothermal Geochemistry. 